\title{
An integrative and quantitative assessment of the gold potential of the Nuuk region, West Greenland
}

\author{
Bo Møller Stensgaard, Thorkild M. Rasmussen and Agnete Steenfelt
}

Visual inspection and comparison of lithological, topographical, geochemical and geophysical maps is a necessary (and often successful) way of interpreting geological features across poorly exposed or poorly explored areas. In mineral exploration, geochemical and geophysical maps are used to visually identify anomalies believed to reflect mineral occurrences. Outcropping mineral occurrences of a certain size can produce elevated concentrations of elements in stream sediment samples, or create magnetic or radioactive signals retrievable by airborne surveys. However, if the regional data are widely spaced, and if the occurrences are small or poorly exposed, the anomalies created may be too subtle to be recognised visually. In such cases, statistical data analyses may help identify deviations from background variations and trends in the data. Furthermore, visually based correlation between distribution patterns on maps is often limited to a few para- meters, and multi-variable relationships are easily overlooked or not possible to deduce.

Gold occurrences in Greenland occur in specific host rocks as a result of mineralising processes, e.g. hydrothermal activity, that have affected a larger area. Thus, the favourable environment for a gold occurrence may be reflected in regional scale survey data as subtle changes in certain geochemical and geophysical properties. If such changes, i.e. a multi-parameter signature for gold mineralisation, can be identified, the regional data can be searched for areas that might hold the same signature.

This paper presents results gained in the application of a statistical spatial analysis method to investigate how known gold showings are expressed in a range of regional datasets from the Nuuk region, southern West Greenland. The main objective is to identify new areas with gold potential, and to

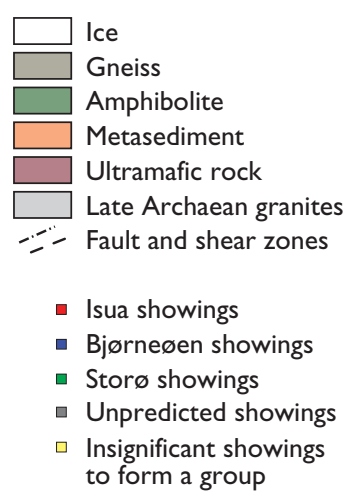

Most favourable areas for:

— Isua gold group

- Bjørneøen gold group

— Storø gold group
Fig. 1. Simplified geological map with $137 \mathrm{~km}^{2}$ (1\% of the analysed area) outlined as most favourable for each of the three groups of gold showings (Isua, Bjørneøen and Storø groups). Outlines of the rock units are from digital versions of 1:100 000 and 1:2 500000 scale geological maps published by the Survey. Q, Qingaaq; A, Aappalaartoq.

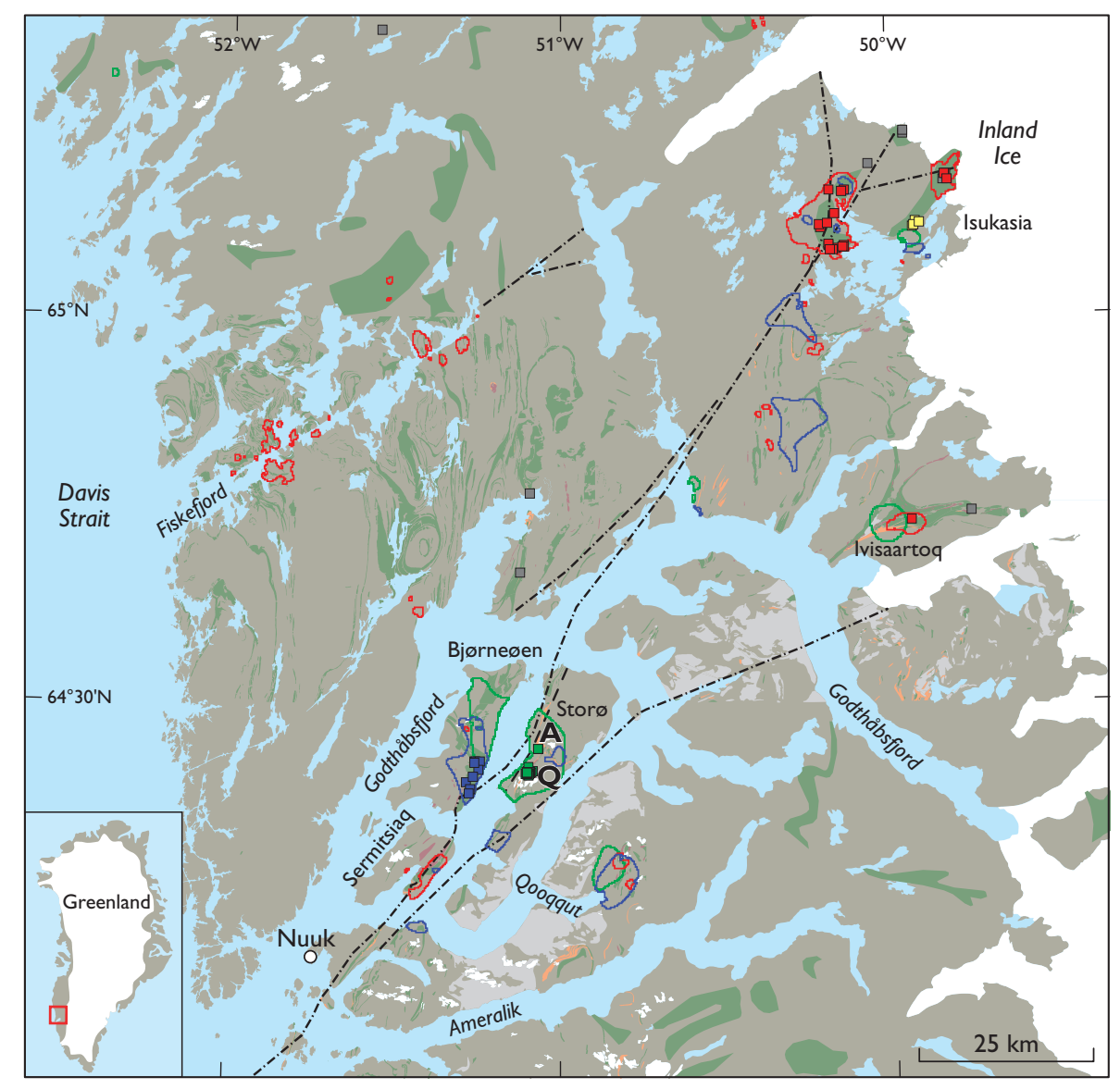


quantify the signatures of the showings. The first tests based on this approach were reported in Nielsen et al. (2004) and Steensgaard et al. (2006).

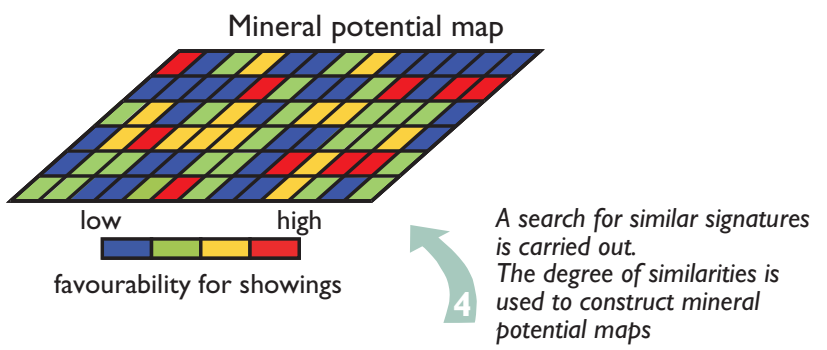

Quantified signatures in different datasets
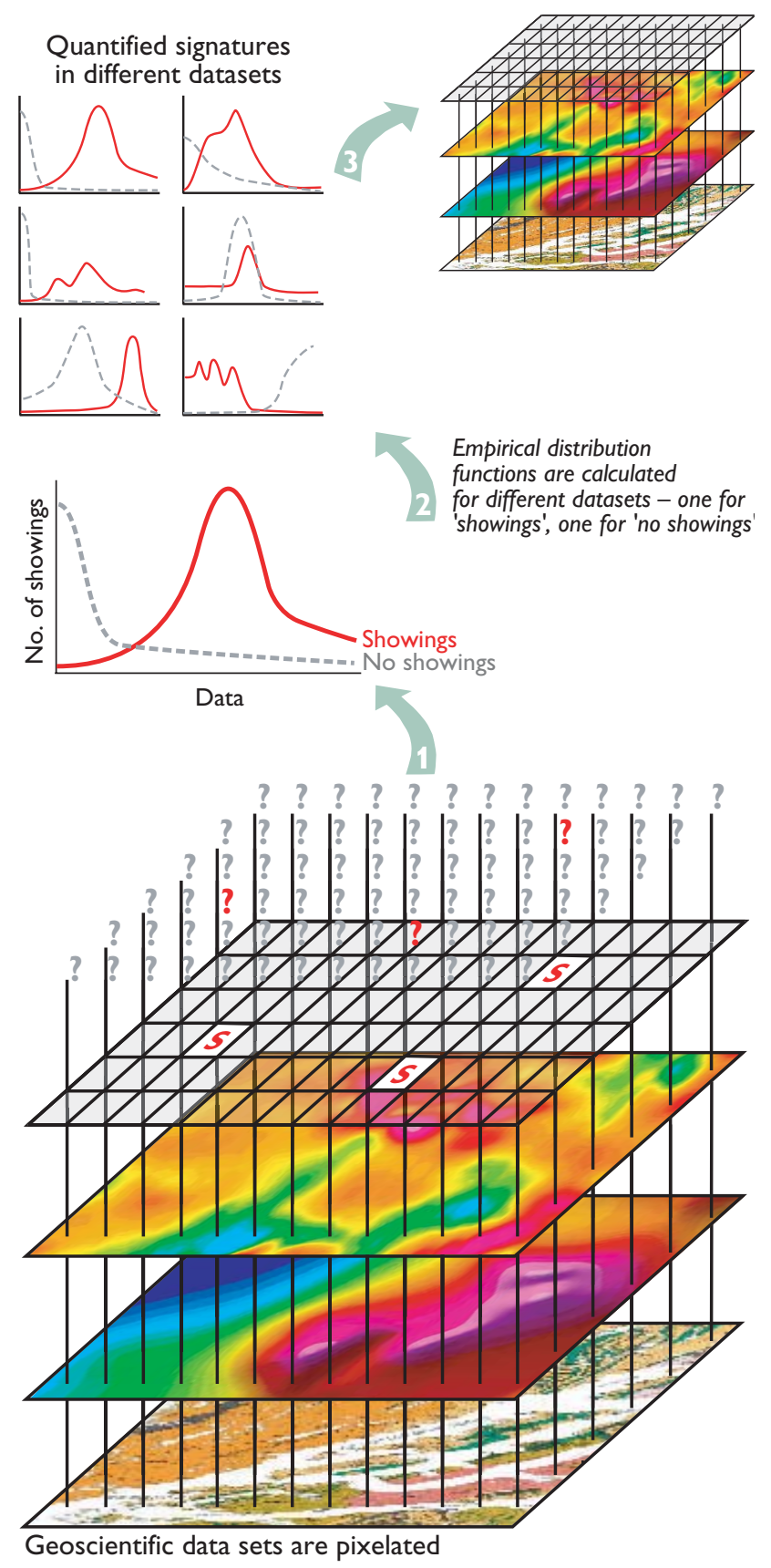

\section{Compilation of available information in databases and company reports}

The Nuuk region is underlain by early to late Archaean rocks dominated by quartzofeldspathic orthogneisses, but with a significant proportion of supracrustal belts, some of which contain greenstones (Fig. 1). The belts represent remnants of Archaean volcanic and associated intrusive rocks, with subordinate chemical and clastic sediments. Recent studies have revealed that the belts represent a number of individual successions formed at different locations and ages. The most common rock type is amphibolite of tholeiitic to komatiitic composition, but andesitic compositions have also been recognised in some belts (Hollis et al. 2005, 2006, this volume). Metasedimentary rocks are mostly garnet-biotite schist. The supracrustal rocks host several gold occurrences in association with hydrothermal alteration (Fig. 1; Appel et al. 2005). Two of these, at Qingaaq and Aappalaartoq on Storø (Q and A, Fig. 1) are currently targets for commercial drilling by NunaMinerals A/S.

\section{Datasets analysed}

Twenty-nine datasets have so far been included in the statistical analysis. The data are derived from regional scale surveys, and comprise stream sediment geochemistry and aeromagnetic data. The geochemical data include concentrations of $\mathrm{Al}_{2} \mathrm{O}_{3}, \mathrm{As}, \mathrm{Au}, \mathrm{CaO}, \mathrm{Cs}, \mathrm{Fe}_{2} \mathrm{O}_{3}, \mathrm{~K}_{2} \mathrm{O}, \mathrm{La}, \mathrm{MgO}$, $\mathrm{Na}_{2} \mathrm{O}, \mathrm{P}_{2} \mathrm{O}_{5}, \mathrm{Rb}, \mathrm{Sb}, \mathrm{SiO}_{2}, \mathrm{Th}, \mathrm{TiO}_{2}, \mathrm{~V}, \mathrm{Zr}, \mathrm{Zn}, \mathrm{U}, \mathrm{Ni} / \mathrm{MgO}$ and $\mathrm{Ni}+\mathrm{Cr}$ in the $<0.1 \mathrm{~mm}$ grain size fraction of stream sediments. The magnetic data include the total magnetic field intensity (TMI), and derivatives of the total field, i.e. vertical gradient of TMI, horizontal gradients of TMI in various directions (HGTMI), and the amplitude of the HGTMI. A search through available non-confidential data reported by exploration companies, as well as Survey databases, provided

Fig. 2. Illustration of the statistical approach. 1: Regional datasets and gold showings (S) are referred to a common grid with fixed cell size. 2 : Empirical distribution functions for cells with and without known gold showings are used to establish the signatures of the showings in each dataset. 3: Likelihood ratio functions for all datasets are calculated as the ratio of the two previous functions, expressing the likeliness of a showing to be present,. Groupings of gold showings are based on constructed mineral potential maps for each showing. Pixel by pixel, these maps outline the predicted favourability for data signatures similar to the selected showing, i.e., the potential for a similar showing to be present. In this way the mutual prediction capability amongst different showings can be compared. 4: Finally, mineral potential maps are calculated for each identified group of showings. These maps are based on the signatures found to be indicative for each of the different groups. 
all known localities from which gold-bearing rock samples had been collected.

\section{Methodology}

The principles of the methodology are illustrated in Fig. 2. All spatial datasets must be converted into a form where they can be compared and subjected to statistical analysis. Each dataset is presented as a regular grid, using a common cell size of $200 \mathrm{~m} \times 200 \mathrm{~m}$, and a gridding procedure based on principles of minimum curvature. Note that the resulting grid values for geochemical and geophysical data are obtained by interpolation, as most measured points of the original datasets have a larger spacing than $200 \mathrm{~m}$. There is therefore a risk that interpolated values in some areas misrepresent the data. Grid cells with and without gold showings are registered. In this study, a gold showing is defined as a cell in which rock samples with $\geq 1 \mathrm{ppm}$ Au have been collected. In total, 52 gold showings were identified.

The data were analysed using statistical methodologies based on Chung (2003, and references therein). In summary, analysing the integrated data signature of cells with gold showings, and using this information to calculate for each cell the probability that it contains a similar gold showing, can be used to construct mineral potential maps. A mineral potential map defines zones or classes of different favourability for a certain mineralisation type. The methodologies involve calculation of empirical distribution functions (EDFs) for cells with and without gold showings, which can be regarded as the signature of the gold showings and the regional background (Fig. 3). The ratio between the two EDFs is used to calculate likelihood ratio functions (LFs) for each dataset. A joint likelihood ratio function (JLF) is then calculated as the product of the LFs. This JLF is then used to construct the mineral potential map.

\section{Grouping of gold showings}

In our first simple approach, we treated all known gold showings as one group (Nielsen et al. 2004). However, the results suggested that some gold showings had different signatures, and statistical methods were subsequently used to test whether the showings could be grouped according to their signatures. A gold potential map was then made for each single showing, based on the datasets that are characteristic of all showings. Then, the capability of the selected showing to predict the remaining showings was evaluated. As a result, a group defined this way consists of showings that have mutual prediction capabilities. The analysis resulted in the identification of three main groups of gold showings (Fig. 1): the Storø group (11 showings in a discrete area at Qingaaq and Aappa- laartoq), the Bjørneøen group (10 showings located around central Bjørneøen), and the Isua group (19 widely spread showings at Isukasia and one showing at Ivisaartoq). Two other groups shown on Fig. 1 are not treated further here, namely a group of eight showings without mutual prediction capabilities with other showings, and another group of four showings which is considered too small to be statistically significant.

\section{Gold potential maps}

Figure 1 displays a gold potential map, where red, blue and green boundaries outline the most favourable areas for finding gold occurrences according to the criteria established for each of the three main groups.

It is not surprising that areas immediately surrounding known gold showings are predicted as favourable, but more interestingly, a number of favourable areas are also predicted outside known gold showings. Many of the latter areas are within or adjacent to supracrustal rocks, that may otherwise be regarded as potential hosts to gold. Some of the most notable favourable areas are east of the fjord Qooqqut, areas on Storø favourable for Bjørneøen group gold showings, and areas on south-eastern Sermitsiaq and farther to the southwest. Finally, several favourable areas are outlined along Fiskefjord (Fig. 1). This area has hardly been prospected for gold, but comprises both supracrustal rocks and structures that are similar to the hosts of some of the known gold showings.
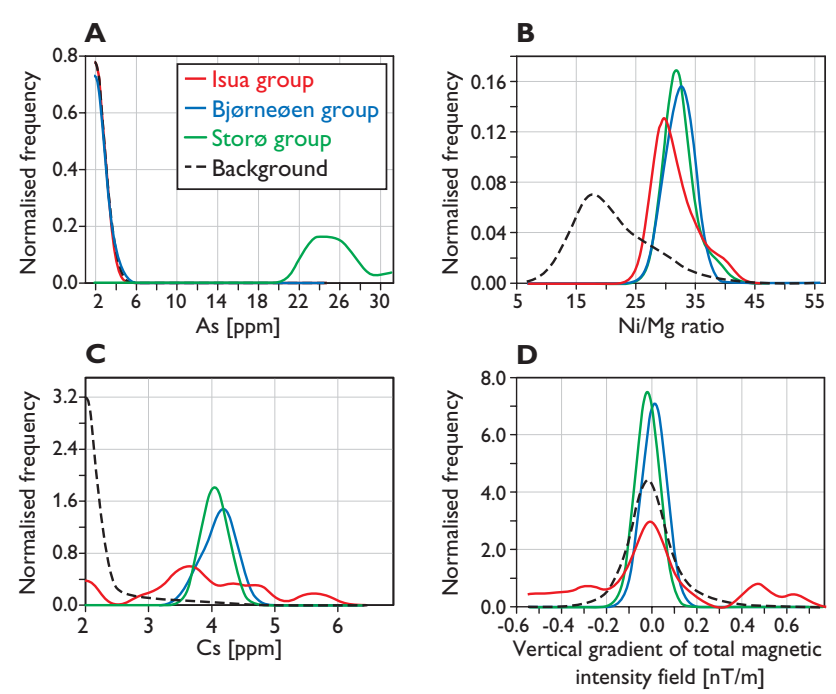

Fig. 3. Single-parameter signatures of three groups of gold showings and the background. A: Arsenic (As), based on concentrations in the fine fraction of stream sediment. B: Nickel/magnesium $(\mathrm{Ni} / \mathrm{Mg})$ ratio, based on concentrations in the fine fraction of stream sediment. $\mathbf{C}$ : Caesium (Cs), based on concentrations in the fine fraction of stream sediment. $\mathbf{D}$ : Vertical gradient (VGTMI), based on airborne measurements of total magnetic field intensity. 
When a mineral potential map for gold is evaluated, it is important to keep in mind that areas outlined as having a low favourability need not necessarily be discarded as targets for gold since the constructed maps only reflect the data and known gold occurrences included in the analysis.

\section{Signatures of gold showings}

The systematic construction of signatures of showings and background (EDFs) draw attention to the significance of parameters that are not immediately or traditionally regarded as indicative of gold mineralisation. This is illustrated in Fig. 3 by four examples of single-parameter empirical distribution functions for each of the three groups of gold showings, together with the background variation.

It has previously been established that the combination of elevated As in stream sediment and gold mineralisation has not been found outside Storø (Fig. 3A). However, the possible significance of the $\mathrm{Ni} / \mathrm{Mg}$ ratio (Fig. $3 \mathrm{~B}$ ) in relation to gold has not previously been substantiated in a quantitative way. This observation is an incentive to conduct further studies of host rock properties in terms of their $\mathrm{Ni}$ and $\mathrm{Mg}$ behaviour.

The rare and unique As signature of the Storø group poses a problem in the search for areas holding a potential for new showings. Since this signature only exists on Storø, only this area will be outlined as favourable for the Storø group. Consequently, the As data are omitted in the calculation of cells with a potential for Storø-type showings. Steenfelt (2000) has argued that Cs may be considered a pathfinder element for gold mineralisation associated with granite-related hydrothermal alteration. The signature for Cs in stream sediment confirms that the gold at Storø and Bjørneøen is indeed located in a Cs-rich environment (Fig. 3C), but also suggests that the mineralisation at Isua has a different nature.

The last example (Fig. 3D) illustrates the indicated significance of the vertical gradient of the total magnetic field intensity (denoted VGTMI). This signature for the Storø and Bjørneøen groups (-0.2 to $0.1 \mathrm{nT} / \mathrm{m}$ ) is identical to the background signature, and is consequently regarded as non-indicative for these groups. The Isua group has a more dispersed signature $(-0.5$ to $0.8 \mathrm{nT} / \mathrm{m})$, with a more highly indicative positive and negative VGTMI than the other groups. This probably reflects local scale changes in lithology. Other datasets, which yield a characteristic signature of one or more of the three groups of gold showings, are the $\mathrm{Au}, \mathrm{Cs}, \mathrm{Rb}, \mathrm{La}$, $T h$, and $U$ concentrations in stream sediment geochemistry.

\section{Further work and perspectives}

The results obtained in the first tests of the applied statistical method have been positive in the sense that areas with high probability for new gold occurrences were outlined in geological settings that would otherwise be regarded as prospective for gold. In the next phase of the study additional datasets will be included, such as airborne gamma-ray spectrometry, digital topography, lithology and structure; the gridding procedure will be refined, and the influence of changing the cell size and the use of other statistical methods will be tested.

This kind of statistical approach has a potential for a range of applications, such as the prediction of other types of mineral occurrences, and identification and mapping of specific rock units in poorly exposed or poorly known terrain. Multivariate statistical analysis seems inevitable as a way to optimise the use of geoscientific data. However, it is important that geoscientists critically evaluate the results of any statistical analysis in order to reveal misleading effects of interpolation and other ways of standardising parameters that by their nature are very variable.

\section{Acknowledgement}

The Bureau of Minerals and Petroleum, Government of Greenland, financially supported the project.

\section{References}

Appel, P.W.U., Coller, D., Coller, V., Heijlen, W., Moberg, E., Polat, A., Raith, J., Schjøth, F., Stendal, H. \& Thomassen, B. 2005: Is there a gold province in the Nuuk region? Danmarks og Grønlands Geologiske Undersøgelse Rapport 2005/27, 79 pp., 1 CD-ROM.

Chung, C.F. 2003: Use of airborne geophysical surveys for constructing mineral potential maps. Economic Geology Monograph 11, 879-891.

Hollis, J.A., van Gool, J.A.M., Steenfelt, A. \& Garde, A.A. 2005: Greenstone belts in the central Godthåbsfjord region, southern West Greenland. Geological Survey of Denmark and Greenland Bulletin 7, 65-68. Hollis, J.A., Frei, D., van Gool, J.A.M., Garde, A.A. \& Persson, M. 2006: Using zircon geochronology to resolve the Archaean geology of southern West Greenland. Geological Survey of Denmark and Greenland Bulletin 10, 25-28.

Nielsen, B.M., Rasmussen, T.M. \& Steenfelt, A. 2004: Gold potential of the Nuuk region based on multi-parameter spatial modelling of known gold showings. Danmarks og Grønlands Geologiske Undersøgelse Rapport 2004/121, 155 pp.

Steenfelt, A. 2001: Geochemical atlas of Greenland - West and South Greenland. Danmarks og Grønlands Geologiske Undersøgelse Rapport 2001/46, 39 pp.

Steensgaard, B.M., Steenfelt, A. \& Rasmussen, T.M. 2006: Gold potential of the Nuuk region based on multi-parameter spatial modelling. Progress 2005. Danmarks og Grønlands Geologiske Undersøgelse Rapport 2006/27, 207 pp. 